\title{
Intellectual Disabilities Behavior Under the Lens of Embodied Cognition Approaches
}

\author{
J. Walter Tolentino-Castro ${ }^{1,2 *}$ and Markus Raab ${ }^{1,3}$ \\ 1 Department of Performance Psychology, Institute of Psychology, German Sport University Cologne, Cologne, Germany, \\ ${ }^{2}$ School of Arts, Sciences and Humanities, University of São Paulo, São Paulo, Brazil, ${ }^{3}$ School of Applied Sciences, London \\ South Bank University, London, United Kingdom
}

Keywords: embodied cognition, mental interventions and body interventions, theoretical testability, intellectual disabilities, impaired cognition, systematic review, meta analysis

\section{INTRODUCTION}

Diverse empirical studies have examined particularities of atypical behavior of the intellectually disabled (ID) population, and just a few theoretical approaches have been empirically tested to further understand the reasons for such atypical behavior (see Berghs et al., 2016, for medical, human rights, and social views about this topic). It is surprising that most of the theoretical approaches tested stem from research with typically developed humans, and have been adapted to partially fit the population in focus here (Bukow, 2013). For instance, Just et al. (2012), Sinha et al. (2014) share a more neuroanatomic view to explain the particularities of atypical behavior, claiming that this population lacks structural and functional body abilities in comparison with typically developed humans (Kaplan et al., 1998). More precisely, it is claimed that the misfunction

Edited by:

Manuel De Vega

University of La Laguna, Spain

Reviewed by:

Filippo Gomez Paloma,

University of Macerata, Italy

${ }^{*}$ Correspondence:

J. Walter Tolentino-Castro w.tolentino.castro@gmail.com

Specialty section: This article was submitted to Theoretical and Philosophical

Psychology,

a section of the journal

Frontiers in Psychology

Received: 21 October 2020

Accepted: 15 June 2021

Published: 12 July 2021

Citation:

Tolentino-Castro JW and Raab M (2021) Intellectual Disabilities Behavior

Under the Lens of Embodied

Cognition Approaches.

Front. Psychol. 12:620083

doi: $10.3389 /$ fpsyg.2021.620083 of specific brain areas are the key elements for their atypical behavior. Indeed, scientific findings have reported mechanisms in which the mentioned neuroanatomic peculiarities impact their cognitive development and vice-versa; which is assumed to guide human behavior (Dye and Pascalis, 2017). Thus, to extend the traditional view a new view on embodied cognition (EC) approaches will explain atypical behavior of the intellectually disabled population (Shapiro, 2011). These approaches claim that body sensorimotor experience is the core stone of cognitive and behavioral development. The discussion though will cover the topic of whether EC approaches can be used to further enlighten the understanding of particularities of atypical behavior of individuals with IDs.

\section{INTELLECTUAL DISABILITIES UNDER THE LENS OF EMBODIED COGNITION APPROACHES}

EC approaches set a new era of cognitive science. It has been claimed that EC describes some of the most complex phenomena of human cognition and behavior, through conceptualization, replacement, and constitution (Shapiro, 2011, p. 9). In more details, conceptualization describes that the properties of an organism's body limit or constrain the concepts an organism can acquire, replacement states that an organism's body in interaction with its environment replaces the need for representational processes thought to have been at the core of cognition; and constitution claims that the body or world plays a constitutive rather than a merely causal role in cognitive processing (Shapiro, 2011). Albeit the explanation from these approaches may cover numerous examples of human behavior, criticism has been advocated recently (Bukow, 2013; Ionescu and Vasc, 2014), given EC may not (equally) well predict behavior for all sorts of human kinds (Shapiro, 2011 , p. 90). At least for those with disabilities, which represent $15 \%$ of the worldwide population 
(WHO, 2011), we want to test the generalizability of the EC claim to the ID population. We argue that the theoretical debate on embodied cognition and the existing scientific evidence in multiple fields and populations indicates that a test of generalizability of EC to the ID population is warranted. Theoretically, embodied cognition approach proposes that abstract concepts are grounded in concrete concepts that can be perceived with our sensorimotor system. It is assumed that the abstract concept of time is based on the concrete concept of space: This is reflected, among other things, in our language: "The evening lies before me" is a sentence with temporal information that is expressed with a spatial expression "before" (Lakoff and Johnson, 1999, p. 34). Empirically, multiple populations of different sensorimotor experiences over the life span have been tested indicating robust evidence in multiple domains and tasks (Löffler et al., 2016).

What follows is guided by two arguments:

First, we discuss the challenges of considering the existent stratum of EC approaches (Smith and Gasser, 2005) to understand the atypical behavior of the mentioned population (Just et al., 2012; De Jaegher, 2013; Franceschini et al., 2017). Note, EC considers the body the center of individuals' experiences to produce a behavior, thus based on EC assumptions an atypical behavior could be a mismatch of environmental information processing and the experience perceived. In other words, given EC claims the relationship with the environment is mandatory to create experiences, any missing information might impact behavior. For instance, an under-estimation or overestimation of the size of the first stair may lead to a dangerous upwards walk of stairs.

Second, we constrain our discussion to atypical behavior to those found in empirical studies; more precisely, assessments made via reliable motor tests in comparison to peers with typical development. For instance, recent literature has shown that persons with IDs perform poorly at motor and cognitive battery tests (Hartman et al., 2010; Westendorp et al., 2011; Houwen et al., 2016). Consequently, as hypothesized by EC approaches, poor motor achievement in motor tests has been claimed to impact cognitive development of persons with IDs, similarly well as for those with typical development (Hartman et al., 2010).

Furthermore, some authors share the view about a tight link between cognition and behavior in this population (De Jaegher, 2013; Hamilton, 2013). Although unclear how, a study suggests the reasons for this population's atypical behavior is based on the known impaired cognitive skills of this population (Lott and Dierssen, 2010). A neuroscientific perspective may describe such suggestion to stem from an abnormal functioning and structural architecture of the brain, as key factors to drive peculiarities in this population's behavior. Although scarce, some pieces of evidence support this perspective's claim (Bartlo and Klein, 2011; Hötting and Röder, 2013).

In extension to neuroscientific perspectives, the persons' experiences that are restricted have been debated. For instance, in a systematic review socialization has been reported as the most prominent source for observed atypical behavior of this population (Hamilton, 2013). In addition, recent empirical evidence suggests that the restricted motor abilities may explain partially the isolated social behavior of persons with autism (De Jaegher, 2013; Sinha et al., 2014). Sinha et al. (2014) reported that adults and children with autism present impaired capacity to predict the next (future) events, e.g., objects and persons that are moving, and thus this may impact directly the development in social groups. It is reported that the avoidance of such social confrontations for those with autism tends to be solved by the use of repetitive motor behavior (Sinha et al., 2014). In the same vein, Tolentino-Castro et al. (2017) and Riddell et al. (2017) extend these findings and report that participants with IDs present an incapacity to recognize other motor behavior patterns and velocities in comparison to the typically developed participants.

The process of deciphering environmental information demand is necessary to generate spatio-temporal representations, which are mandatory to create event predictions (Shapiro, 2011). Noteworthy, findings from experimental studies (Recanzone, 2009) state that preserved "channels" (e.g., eyes and ears) are essential to deciphering physical environmental information demands (e.g., sound, light, texture, vibration) and that these sensory inputs are less development in the ID population due to restricted sensorimotor experiences. We argue that it seems that the ID population presents impairments to process and use environmental information to generate sensorimotor interaction with the natural and human environment. In other words, taking sensorimotor experience as a complex interlink between the perception of the world and motor output, as predicted by EC approaches, it follows that ID have either less or incomplete (processed) sensory information and atypical motor behavior need to be explained within a joint EC approach (Dye and Pascalis, 2017). How good can such an alternative perspective explain atypical behavior of individuals with IDs? We argue this needs an empirical test to show that beyond brain abnormalities on cognitive and behavioral development sensorimotor experiences explain behavior and may challenge or extend therapeutic interventions (Roubertoux and Carlier, 2007; Enea-Drapeau et al., 2017).

\section{IS THERE A WAY TO CHANGE AN EXPLANATION ABOUT THE BEHAVIOR OF THE ID POPULATION?}

A key problem of the popular thinking and the literature regarding this topic is the claim that:

1. Not much or no considerable behavioral change can be achieved in this population (Hamilton, 2013).

2. No cognitive development is possible for those with IDs (Enea-Drapeau et al., 2017).

We argue that those claims do not reflect the current state of scientific findings (Molina-García and Vived, 2004; Kozulin et al., 2010). Kozulin et al. (2010) in line with Molina-García and Vived (2004) report that to some extent this population is able to have cognitive improvement; for instance, individuals diagnosed with Down syndrome and developmentally disabled participants. 
TABLE 1 | Overview of the 10 most cited reviews in regards to the topics body and mental interventions for intellectual disabled population.

\begin{tabular}{|c|c|c|c|c|c|c|c|c|c|c|}
\hline \multicolumn{11}{|l|}{ Section BODY } \\
\hline Authors & $\begin{array}{l}\text { Bondár et al. } \\
\text { (2020) }\end{array}$ & $\begin{array}{l}\text { Fonzo et al. } \\
(2020)\end{array}$ & $\begin{array}{l}\text { Ruiz- } \\
\text { González } \\
\text { et al. (2019) }\end{array}$ & $\begin{array}{l}\text { Kapsal et al. } \\
\text { (2019) }\end{array}$ & $\begin{array}{l}\text { Maiiano et al. } \\
\text { (2019) }\end{array}$ & $\begin{array}{l}\text { May et al. } \\
\text { (2019) }\end{array}$ & $\begin{array}{l}\text { Paul et al. } \\
\text { (2019) }\end{array}$ & $\begin{array}{l}\text { Harris et al. } \\
\text { (2015) }\end{array}$ & $\begin{array}{l}\text { Ogg- } \\
\text { Groenendaal } \\
\text { et al. (2014) }\end{array}$ & Li et al. (2013) \\
\hline $\begin{array}{l}\text { Number of } \\
\text { studies reviewed }\end{array}$ & 13 & 22 & 27 & 109 & 14 & 19 & 19 & 6 & 20 & 10 \\
\hline $\begin{array}{l}\text { Number of } \\
\text { studies based on } \\
\text { any theoretical } \\
\text { background }\end{array}$ & 7 & Not reported & Not reported & Not reported & Not reported & Not reported & Not reported & Not reported & Not reported & 5 \\
\hline $\begin{array}{l}\text { Number of } \\
\text { participants }\end{array}$ & 598 & 54 & 842 & 4200 & 464 & 521 & 1331 & 178 & 91 & 349 \\
\hline $\begin{array}{l}\% \text { of Gender } \\
\text { (female/male/*) }\end{array}$ & Not reported & Not reported & $\begin{array}{l}60.1 \% \text { male } \\
39.9 \% \text { women }\end{array}$ & Not reported & $\begin{array}{l}57.3 \% \text { boys } \\
\text { (children } \\
\text { studies), } \\
51.7 \% \text { men } \\
\text { (adult studies) }\end{array}$ & Not reported & Not reported & Not reported & $\begin{array}{l}34 \text { male } \\
9 \text { female } \\
48^{\star}\end{array}$ & $\begin{array}{l}\text { "In general, there } \\
\text { were more male } \\
\text { than female } \\
\text { participants" }\end{array}$ \\
\hline $\begin{array}{l}\% \text { of Body } \\
\text { interventions } \\
\text { used }\end{array}$ & $\begin{array}{l}85 \% \text { of the } \\
\text { eligible } \\
\text { studies } \\
\text { described as } \\
\text { PA }\end{array}$ & $\begin{array}{l}9.1 \% \text { applied } \\
\text { behavior } \\
\text { analysis } \\
4.5 \% \\
\text { conductive } \\
\text { education } \\
4.5 \% \\
\text { environmental } \\
\text { enrichment } \\
18.2 \% \\
\text { traditional } \\
\text { physical } \\
\text { therapy with } \\
\text { or without } \\
\text { aids, } \\
9.1 \% \\
\text { hydrotherapy } \\
9.1 \% \\
\text { treadmill } \\
13.6 \% \text { music } \\
\text { therapy } \\
27.3 \% \\
\text { computerized } \\
\text { systems } \\
4.5 \% \\
\text { sensory- } \\
\text { based treatment }\end{array}$ & $\begin{array}{l}18.52 \% \\
\text { aerobic } \\
\text { training } \\
29.63 \% \\
\text { resistance } \\
\text { training } \\
22.22 \% \\
\text { mixed training } \\
7.4 \% \text { balance } \\
\text { training } \\
7.4 \% \\
\text { vibration PA } \\
7.4 \% \text { early } \\
\text { stimulation } \\
7.4 \% \\
\text { Technical aid }\end{array}$ & $\begin{array}{l}23.2 \% \\
\text { aerobic PA } \\
7.1 \% \text { RE } \\
\text { training PA } \\
27.1 \% \text { move } \\
\text { skills PA } \\
35.5 \% \\
\text { general } \\
\text { PA/PE } \\
6.5 \% \text { based } \\
\text { on balance or } \\
\text { core stability }\end{array}$ & $\begin{array}{l}21.4 \% \\
\text { balance } \\
\text { and/or } \\
\text { strength } \\
\text { exercises } \\
7.1 \% \\
\text { adapted play } \\
\text { training } \\
7.1 \% \\
\text { handball } \\
\text { techniques } \\
7.1 \% \\
\text { compute } \\
\text { games } \\
7.1 \% \\
\text { therapeutic } \\
\text { sensorimotor } \\
\text { training } \\
7.1 \% \text { physical } \\
\text { development } \\
\text { training } \\
7.1 \% \\
\text { intensive } \\
\text { motor skills } \\
\text { training } \\
7.1 \% \text { physical } \\
\text { therapy } \\
7.1 \% \\
\text { vestibular } \\
\text { stimulation exer }\end{array}$ & 100\% Dance & $\begin{array}{l}5.3 \% \text { Judo } \\
47.4 \% \text { TM } \\
10.5 \% \text { weight } \\
\text { training } \\
5.3 \% \text { bike } \\
10.5 \% \text { Wii e- } \\
\text { sports gaming }\end{array}$ & $\begin{array}{l}16.6 \% \text { bicycle } \\
\text { ergometer } \\
16.6 \% \\
\text { strength and } \\
\text { endurance } \\
\text { training } \\
16.6 \% \\
\text { plyometric } \\
\text { jumps training } \\
16.6 \% \text { whole } \\
\text { body vibration } \\
\text { and isometric } \\
\text { exercise } \\
16.6 \% \\
\text { treadmill } \\
\text { ergometer } \\
16.6 \% \\
\text { rowing ergometer }\end{array}$ & $\begin{array}{l}40 \% \\
\text { walking/jogging, } \\
15 \% \text { aerobic } \\
\text { exercise } \\
10 \% \text { football } \\
5 \% \text { dance } \\
5 \% \text { basketball } \\
5 \% \\
\text { calisthenics } \\
5 \% \text { roller } \\
\text { skating } \\
15 \% \text { general } \\
\text { motor training }\end{array}$ & $\begin{array}{l}10 \% \text { Treadmill TP } \\
10 \% \text { bicycle TP } \\
10 \% \text { rowing } \\
\text { ergometer TP } \\
20 \% \text { progressive } \\
\text { resistance TP } \\
10 \% \text { combined TP } \\
\text { with treadmill and } \\
\text { game-like exercise } \\
10 \% \text { combined TP } \\
\text { with progressive } \\
\text { resistance training } \\
\text { and balance } \\
\text { exercise } \\
20 \% \text { combined TP } \\
\text { with } \\
\text { cardiovascular and } \\
\text { strength exercise, } \\
10 \% \\
\text { weight-bearing } \\
\text { exercise TP }\end{array}$ \\
\hline
\end{tabular}


TABLE 1 | Continued

\begin{tabular}{|c|c|c|c|c|c|c|c|c|c|c|}
\hline \multicolumn{11}{|l|}{ Section MENTAL } \\
\hline Authors & $\begin{array}{l}\text { Surley and } \\
\text { Dagnan } \\
\text { (2019) }\end{array}$ & $\begin{array}{l}\text { Patterson } \\
\text { et al. (2019) }\end{array}$ & $\begin{array}{l}\text { Cooney et al. } \\
\text { (2018) }\end{array}$ & $\begin{array}{l}\text { Stott et al. } \\
(2017)\end{array}$ & $\begin{array}{l}\text { McNair et al. } \\
\text { (2017) }\end{array}$ & $\begin{array}{l}\text { Hellenbach } \\
\text { et al. (2015) }\end{array}$ & $\begin{array}{l}\text { Ali et al. } \\
\text { (2015) }\end{array}$ & $\begin{array}{l}\text { Vereenooghe } \\
\text { and Langdon } \\
\text { (2013) }\end{array}$ & $\begin{array}{l}\text { Hwang and } \\
\text { Kearney } \\
\text { (2013) }\end{array}$ & Nicoll et al. (2013) \\
\hline $\begin{array}{l}\text { Number of } \\
\text { studies reviewed }\end{array}$ & 23 & 20 & 18 & 12 & 7 & 4 & 6 & 22 & 19 & 12 \\
\hline $\begin{array}{l}\text { Number of } \\
\text { studies based on } \\
\text { any theoretical } \\
\text { background }\end{array}$ & 23 & Not reported & 18 & 6 & Not reported & Not reported & Not reported & Not reported & Not reported & 12 \\
\hline $\begin{array}{l}\text { Number of } \\
\text { participants }\end{array}$ & 319 & 109 & 798 & 554 & 89 & 72 & 309 & 847 & Not reported & 315 \\
\hline $\begin{array}{l}\% \text { of Gender } \\
(\text { female/male/*) }\end{array}$ & Not reported & Not reported & Not reported & ID & Not reported & ID & $\begin{array}{l}\text { Not reported } \\
\text { in all studies }\end{array}$ & Not reported & Not reported & $\begin{array}{l}74.9 \% \text { male } \\
25.1 \% \text { female }\end{array}$ \\
\hline $\begin{array}{l}\% \text { of Mental } \\
\text { interventions } \\
\text { used }\end{array}$ & $\begin{array}{l}\text { 91.3\% } \\
\text { general CBT } \\
8.7 \% \\
\text { manualized CBT }\end{array}$ & $\begin{array}{l}45 \% \\
\text { mindfulness- } \\
\text { based } \\
\text { approach } \\
30 \% \text { DBT } \\
15 \% \text { CFT } \\
10 \% \text { ACT }\end{array}$ & $\begin{array}{l}44.5 \% \text { CBT } \\
\text { with multiple } \\
\text { cognitive } \\
\text { therapy skills, } \\
44.5 \% \\
\text { abilities to } \\
\text { recognize } \\
\text { emotions } \\
5.5 \% \\
\text { cognitive } \\
\text { mediation } \\
5.5 \% \text { abilities } \\
\text { to access } \\
\text { beliefs alone } \\
\text { in relation to } \\
\text { events in } \\
\text { which they } \\
\text { experienced anger }\end{array}$ & $\begin{array}{l}100 \% \text { general } \\
\text { CBT }\end{array}$ & $\begin{array}{l}35 \% \text { DBT } \\
20 \% \\
\text { individual } \\
\text { therapy } \\
45 \% \text { different } \\
\text { types of } \\
\text { personal consult }\end{array}$ & $\begin{array}{l}50 \% \\
\text { education } \\
\text { program } \\
50 \% \\
\text { relaxation } \\
\text { treatment } \\
\text { and anger }\end{array}$ & $\begin{array}{l}44 \% \text { anger } \\
\text { management } \\
14 \% \text { one } \\
\text { individual } \\
\text { therapy and } \\
\text { two } \\
\text { group-based } \\
14 \% \\
\text { relaxation } \\
14 \% \\
\text { mindfulness } \\
\text { based on } \\
\text { meditation } \\
14 \% \text { problem } \\
\text { solving and } \\
\text { assertiveness tr }\end{array}$ & $\begin{array}{l}\text { 82\% general } \\
\text { CBT } \\
9 \% \\
\text { group-based } \\
\text { psychotherapy } \\
\text { 9\% other } \\
\text { individual } \\
\text { psychotherapy }\end{array}$ & $\begin{array}{l}53 \% \\
\text { meditation } \\
21 \% \text { mindful } \\
\text { observation of } \\
\text { thoughts, } \\
\text { feeling or } \\
\text { food } \\
11 \% \text { body, } \\
\text { thoughts or } \\
\text { food } \\
\text { awareness } \\
5 \% \text { CBT } \\
5 \% \text { Intention }\end{array}$ & $100 \%$ general CBT \\
\hline
\end{tabular}

PA, Physical Activity; PE, Physical Education; TP, Training Program; ACT, Acceptance and Commitment Therapy; CBT, Cognitive Behavioral Therapy; CFT, Compassion Focused Therapy; DBT, Dialetical Behavioral Therapy; ID, Incongruous description; TM, Treadmill; RE, Resistance; *not reported. 
The question which arrives is, which knowledge exit about effective changes in ID's atypical behavior and how does it impact current therapeutics, training, and interventions for this population? Table 1 was tailored to address this aim. It contains the 20 most cited reviews (systematic reviews or metaanalyses) regarding interventions for the intellectual disabled population. More precisely, we've selected the 10 most cited reviews which used body interventions, for instance: sport, physical activities and/or gymnastic; and 10 most cited reviews which used mental interventions, for instance: mental training, behavioral training and/or psychological therapy. Noteworthy is that the motivation to split the search in physical and mental training is based on the absence of any meta-analyses and systematic reviews that allow to describe moderators of both specific training regimes. Under the lens of EC, this might be mandatory because cognitive and behavioral development is a product of the interaction between person and environment. The search preferred reporting items (see Appendix 1) for systematic reviews and meta-analyses (PRISMA) published in the last 10 years (2010 onwards) for systematic reviews and meta-analyses, has been used for reporting rapid reviews, see Table 1.

We showed above that not much empirical studies with this population have been driven by a theoretical approach. Especially, none of those scientific studies has tested/falsified EC approaches assumptions. In addition, in Table 1 (see section BODY) the majority of the intervention was performed individually (see row "\% of Body interventions used") and we propose to have group interventions to enhance sensorimotor learning by movement observation and sensorimotor social interactions. We can conclude that instead of using therapeutic interventions to control for the social weakness of this population, it may reinforce the social isolation between the peers and reduces potential development. In regards to Table 1 (see section MENTAL) it seems that the therapeutic interventions were driven more to avoid or minimize further other comorbid atypical behavior such as fear, anger, and sexual aggression behaviors. The fact that only a few interventions were motivated by a theoretical assumption may lead to a less evidencebased routine of practitioners and may not allow innovation in intervention strategies. Such a theory-practice gap seems to be evident in many graduate courses of psychology, physiotherapy, sports science, or medicine that often fail to combine theoretical models for typically developed humans and test how to generalize them to individuals with special needs. Likewise, most empirical evidence in the EC perspective has been conducted in the normal student population and thus generalizability is open to future research opportunities. The main idea of Table $\mathbf{1}$ is to give an overview about the current empirical evidence in this field by presenting the 10 most cited reviews. We believe that the table might help the reader to understand how our opinion is based in a systematic description of existing reviews.

\section{RESEARCH OPPORTUNITIES}

Given that experimental studies reported in Table 1 suggested diverse positive effect on cognitive and behavioral development for those with IDs, either for interventions focused in the physical or mental training, the follow research opportunities could be considered. First, follow-up studies should test whether "intervention embedded in EC approaches" (Dandashi et al., 2015) have stronger effect on participants' cognitive and behavioral development than the interventions focusing purely on physical or mental training. Second, by comparing embodied cognition and non-embodied cognition interventions future research will be able to quantify and specify the effects of interventions in ID populations.

Finally, in regard to our main aim, we state the valuable impact of EC approaches to explain atypical behavior in the ID population is an opinion that deserves empirical evidence. However, we do not know the full picture of the underlying mechanisms involved in ID's atypical behavior and moderators such as kind or level of disabilities. A test of the null hypothesis of having no positive acute effect of "intervention embedded in EC approaches" compared to currently used interventions against a hypothesis that a larger change of atypical behavior in ID's can be achieved by EC interventions is an empirical question. A few researchers started to investigate sensorimotor training interventions in ID for chronic effects of longer duration (Dandashi et al., 2015). As argued above, it's an empirical test that is open for validation. In this opinion we argue that cognitive and behavioral development driven by interventions can be supported and profit from EC approaches in person with IDs. Are you ready to take this opinion to an empirical test?

\section{AUTHOR CONTRIBUTIONS}

The authors confirm being the sole contributor of their work and have approved it for publication.

\section{FUNDING}

The project was supported by the German Research Foundation (DFG) awarded to MR (RA 940/15-2).

\section{ACKNOWLEDGMENTS}

We want to warmly extend our thanks to Johannes Meyer and Ricardo Pereira Alcantara Júnior, for their contribution in the manuscript development.

\section{SUPPLEMENTARY MATERIAL}

The Supplementary Material for this article can be found online at: https://www.frontiersin.org/articles/10.3389/fpsyg. 2021.620083/full\#supplementary-material 


\section{REFERENCES}

Ali, A., Hall, I., Blickwedel, J., and Hassiotis, A. (2015). Behavioural and cognitive-behavioural interventions for outwardly-directed aggressive behaviour in people with intellectual disabilities. Cochrane Database Syst. Rev. 2015:CD003406. doi: 10.1002/14651858.CD003406.pub4

Bartlo, P., and Klein, P. J. (2011). Physical Activity benefits and needs in adults with intellectual disabilities: systematic review of the literature. Am. J. Intellect. Dev. Disabil. 116, 220-232. doi: 10.1352/1944-7558-116.3.220

Berghs, M., Atkin, K., Graham, H., Hatton, C., and Thomas, C. (2016). Implications for Public Health Research of Models and Theories of Disability: A Scoping Study and Evidence Synthesis. Southampton, UK: NIHR Journals Library.

Bondár, R. Z., di Fronso, S., Bortoli, L., Robazza, C., Metsios, G. S., and Bertollo, M. (2020). The effects of physical activity or sport-based interventions on psychological factors in adults with intellectual disabilities: a systematic review. J. Intellect. Disabil. Res. 64, 69-92. doi: 10.1111/jir.12699

Bukow, G. C. (2013). On the use and misuse of externalist approaches in psychiatry. Front. Psychol. 4:785. doi: 10.3389/fpsyg.2013.00785

Cooney, P., Tunney, C., and O'Reilly, G. (2018). A systematic review of the evidence regarding cognitive therapy skills that assist cognitive behavioural therapy in adults who have an intellectual disability. J. Appl. Res. Intellect. Disabil. 31, 23-42. doi: 10.1111/jar.12365

Dandashi, A., Karkar, A. G., Saad, S., Barhoumi, Z., Al-Jaam, J., and El Saddik, A. (2015). Enhancing the cognitive and learning skills of children with intellectual disability through physical activity and edutainment games. Int. J. Distribut. Sens. Networks 11:6. doi: 10.1155/2015/165165

De Jaegher, H. (2013). Embodiment and sense-making in autism. Front. Integr. Neurosci. 7:15. doi: 10.3389/fnint.2013.00015

Dye, M. W. G., and Pascalis, O. (2017). Editorial: the sensation-cognition interface: impact of early sensory experiences on cognition. Front. Psychol. 8:1742. doi: 10.3389/fpsyg.2017.01742

Enea-Drapeau, C., Carlier, M., and Huguet, P. (2017). Implicit theories concerning the intelligence of individuals with Down syndrome. PLoS ONE 12:e0188513. doi: 10.1371 /journal.pone. 0188513

Fonzo, M., Sirico, F., and Corrado, B. (2020). Evidence-based physical therapy for individuals with rett syndrome: a systematic review. Brain Sci. 10:410. doi: 10.3390/brainsci10070410

Franceschini, S., Trevisan, P., Ronconi, L., Bertoni, S., Colmar, S., Double, K., et al. (2017). Action video games improve reading abilities and visual-to-auditory attentional shifting in English-speaking children with dyslexia. Sci. Rep. 7:5863. doi: 10.1038/s41598-017-05826-8

Hamilton, L. A. F. C. (2013). Reflecting on the mirror neuron system in autism: a systematic review of current theories. Dev. Cogn. Neurosci. 3, 91-105. doi: 10.1016/j.dcn.2012.09.008

Harris, L., Hankey, C., Murray, H., and Melville, C. (2015). The effects of physical activity interventions on preventing weight gain and the effects on body composition in young adults with intellectual disabilities: systematic review and meta-analysis of randomized controlled trials. Clin. Obes. 5, 198-210. doi: $10.1111 /$ cob.12103

Hartman, E., Houwen, S., Scherder, E., and Visscher, C. (2010). On the relationship between motor performance and executive functioning in children with intellectual disabilities. J. Intellect. Disabil. Res. 54, 468-477. doi: 10.1111/j.1365-2788.2010.01284.x

Hellenbach, M., Brown, M., Karatzias, T., and Robinson, R. (2015). Psychological interventions for women with intellectual disabilities and forensic care needs: a systematic review of the literature. J. Intellect. Disabil. Res. 59, 319-331. doi: 10.1111/jir.12133

Hötting, K., and Röder, B. (2013). Beneficial effects of physical exercise on neuroplasticity and cognition. Neurosci. Biobehav. Rev. 37 (9 Pt B), 2243-2257. doi: 10.1016/j.neubiorev.2013.04.005

Houwen, S., Visser, L., van der Putten, A., and Vlaskamp, C. (2016). The interrelationships between motor, cognitive and language development in children with and without intellectual and developmental disabilities. Res. Dev. Disabil. 53-54, 19-31. doi: 10.1016/j.ridd.2016.01.012

Hwang, Y. S., and Kearney, P. (2013). A systematic review of mindfulness intervention for individuals with developmental disabilities: longterm practice and long lasting effects. Res. Dev. Disabil. 34, 314-326. doi: $10.1016 /$ j.ridd. 2012.08 .008
Ionescu, T., and Vasc, D. (2014). Embodied cognition: challenges for psychology and education. Proc. Soc. Behav. Sci. 128, 275-280. doi: 10.1016/j.sbspro.2014.03.156

Just, M. A., Keller, T. A., Malave, V. L., Kana, R. K., and Varma, S. (2012). Autism as a neural systems disorder: a theory of frontal-posterior underconnectivity. Neurosci. Biobehav. Rev. 36, 1292-1313. doi: 10.1016/j.neubiorev.2012.02.007

Kaplan, B. J. N., Wilson, B., Dewey, D., and Crawford, S. G. (1998). DCD may not be a discrete disorder. Hum. Mov. Sci. 17, 471-490. doi: 10.1016/S0167-9457(98)00010-4

Kapsal, N. J., Dicke, T., Morin, A. J., Vasconcellos, D., Maïano, C., Lee, J., et al. (2019). Effects of physical activity on the physical and psychosocial health of youth with Intellectual disabilities: a systematic review and meta-analysis. $J$. Phys. Act. Health 16, 1187-1195. doi: 10.1123/jpah.2018-0675

Kozulin, A., Lebeer, J., Madella-Noja, A., Gonzalez, F., Jeffrey, I., Rosenthal, N., et al. (2010). Cognitive modifiability of children with developmental disabilities: a multicenter study using Feuerstein's Instrumental Enrichment. Basic program. Res. Dev. Disabil. 31, 551-559. doi: 10.1016/j.ridd.2009. 12.001

Lakoff, G., and Johnson, M. (1999). Philosophy in the Flesh: The Embodied Mind and Its Challenge to Western Thought. New York, NY: Basic Books.

Li, C., Chen, S., How, Y. M., and Zhang, A. L. (2013). Benefits of physical exercise intervention on fitness of individuals with Down syndrome: a systematic review of randomized-controlled trials. Int. J. Rehabil. Res. 36, 187-195. doi: 10.1097/MRR.0b013e3283634e9c

Löffler, J., Raab, M., and Cañal-Bruland, R. (2016). A lifespan perspective on embodied cognition. Front. Psychol. 7:845. doi: 10.3389/fpsyg.2016.00845

Lott, I. T., and Dierssen, M. (2010). Cognitive deficits and associated neurological complications in individuals with Down's syndrome. Lancet Neurol. 9, 623-633. doi: 10.1016/S1474-4422(10)70112-5

Maïano, C., Hue, O., and April, J. (2019). Effects of motor skill interventions on fundamental movement skills in children and adolescents with intellectual disabilities: a systematic review. J. Intellect. Disabil. Res. 63, 1163-1179. doi: $10.1111 /$ jir.12618

May, T., Chan, E. S., Lindor, E., McGinley, J., Skouteris, H., Austin, D., et al. (2019). Physical, cognitive, psychological and social effects of dance in children with disabilities: systematic review and meta-analysis. Disabil. Rehabil. 43, 1-14. doi: 10.1080/09638288.2019.1615139

McNair, L., Woodrow, C., and Hare, D. (2017). Dialectical behaviour therapy [DBT] with people with intellectual disabilities: a systematic review and narrative analysis. J. Appl. Res. Intellect. Disabil. 30, 787-804. doi: $10.1111 /$ jar.12277

Molina-García, S., and Vived, C. E. (2004). Improvement of cognitive functions in children with down syndrome through the bright start program. J. Cogn. Educ. Psychol. 4, 65-86. doi: 10.1891/194589504787382956

Nicoll, M., Beail, N., and Saxon, D. (2013). Cognitive behavioural treatment for anger in adults with intellectual disabilities: a systematic review and metaanalysis. J. Appl. Res. Intellect. Disabil. 26, 47-62. doi: 10.1111/jar.12013

Ogg-Groenendaal, M., Hermans, H., and Claessens, B. (2014). A systematic review on the effect of exercise interventions on challenging behavior for people with intellectual disabilities. Res. Dev. Disabil. 35, 1507-1517. doi: 10.1016/j.ridd.2014.04.003

Patterson, C. W., Williams, J., and Jones, R. (2019). Third-wave therapies and adults with intellectual disabilities: a systematic review. J. Appl. Res. Intellect. Disabil. 32, 1295-1309. doi: 10.1111/jar.12619

Paul, Y., Ellapen, T. J., Barnard, M., Hammill, H. V., and Swanepoel, M. (2019). The health benefits of exercise therapy for patients with Down syndrome: a systematic review. Afr. J. Disabil. 8:576. doi: 10.4102/ajod.v8i0.576

Recanzone, G. H. (2009). Interactions of auditory and visual stimuli in space and time. Hear. Res. 258, 89-99. doi: 10.1016/j.heares.2009.04.009

Riddell, H., Tolentino-Castro, J. W., and Lappe, M. (2017). Impairments in the visual processing of global biological motion cues in down syndrome. Perception. 46:301006617718716. doi: 10.1177/0301006617718716

Roubertoux, P. L., and Carlier, M. (2007). From DNA to mind. EMBO Rep. 8, S7-11. doi: 10.1038/sj.embor.7400991

Ruiz-González, L., Lucena-Antón, D., Salazar, A., Martín-Valero, R., and MoralMunoz, J. A. (2019). Physical therapy in Down syndrome: systematic review and meta-analysis. J. Intellect. Disabil. Res. 63, 1041-1067. doi: $10.1111 /$ jir.12606 
Shapiro, L. (2011). Embodied Cognition (New Problems of Philosophy). New York, NY: Routledge.

Sinha, P., Kjelgaard, M. M., Gandhi, T. K., Tsourides, K., Cardinaux, A. L., Pantazis, D., et al. (2014). Autism as a disorder of prediction. Proc. Natl. Acad. Sci. 111, 15220-5. doi: 10.1073/pnas.1416797111

Smith, L. B., and Gasser, M. (2005). The development of embodied cognition: six lessons from babies. Artif. Life 11, 13-30. doi: 10.1162/1064546053278973

Stott, J., Charlesworth, G., and Scior, K. (2017). Measures of readiness for cognitive behavioural therapy in people with intellectual disability: a systematic review. Res. Dev. Disabil. 60, 37-51. doi: 10.1016/j.ridd.2016.11.003

Surley, L., and Dagnan, D. (2019). A review of the frequency and nature of adaptations to cognitive behavioural therapy for adults with intellectual disabilities. J. Appl. Res. Intellect. Disabil. 32, 219-237. doi: 10.1111/jar.12534

Tolentino-Castro, J. W., Riddell, H., and Wagner, H. (2017). Perception of Biological motion speed in individuals with down syndrome. J. Down Syndr. Chromosome Abnormal. 3, 1-6. doi: 10.4172/2472-1115.1000123

Vereenooghe, L., and Langdon, P. E. (2013). Psychological therapies for people with intellectual disabilities: a systematic review and meta-analysis. Res. Dev. Disabil. 34, 4085-4102. doi: 10.1016/j.ridd.2013.08.030
Westendorp, M., Houwen, S., Hartman, E., and Visscher, C. (2011). Are gross motor skills and sports participation related in children with intellectual disabilities? Res. Dev. Disabil. 32, 1147-1153. doi: 10.1016/j.ridd.2011. 01.009

WHO (2011). World Report on Disabilitiy. Available online at: http://apps.who. int/iris/bitstream/handle/10665/70670/WHO_NMH_VIP_11.01_eng.pdf? sequence $=1$ (accessed December 20, 2019).

Conflict of Interest: The authors declare that the research was conducted in the absence of any commercial or financial relationships that could be construed as a potential conflict of interest.

Copyright (c) 2021 Tolentino-Castro and Raab. This is an open-access article distributed under the terms of the Creative Commons Attribution License (CC BY). The use, distribution or reproduction in other forums is permitted, provided the original author(s) and the copyright owner(s) are credited and that the original publication in this journal is cited, in accordance with accepted academic practice. No use, distribution or reproduction is permitted which does not comply with these terms. 